\title{
SHEA, AIDS, and Public Policy
}

This has been a summer of escalating public and political concerns about the human immunodeficiency virus (HIV)infected healthcare worker. The SHEA AIDS Committee (Drs. Michael Tapper [chair], Gordon Dickinson, Julie Gerberding, David Henderson, and Frank Rhame) has been working overtime to represent and present SHEA's viewpoints.

Of particular note, SHEA was an invited participant at the Centers for Disease Controls (CDC)
August 7, 1991, meeting in Atlanta, Georgia, which was convened to "exposure prone" invasive procedures. At the American Medical Association's (AMA) August 28, 1991, meeting in Chicago, Illinois, which was held to discuss this same issue, Dr. Tapper also made an invited presentation and recounted the Society's position on healthcare worker screening vis-a-vis invasive procedures.

And most recently, Dr. Glen facilitate the process of identifying

Mayhall represented SHEA at a national press conference on August 29, 1991, in Washington, DC. The goal of the press conference, at which Dr. Mayhall issued a statement and took questions, was to place the issue of HIV transmission from healthcare workers to patients in proper perspective. Other participants at the news conference were former Surgeon General C. Everett Koop, $\mathrm{MD}$, and representatives from the AMA and CDC.

\section{ASM Update}

The Centers for Disease Control (CDC) recently issued a comprehensive Morbidity and Mortality Weekly Report (M M WR) supplement on "Guidelines for Preventing the Transmission of Tuberculosis in Healthcare Settings, With Special Focus on HIV-Related Issues" (MMWR. 1990;39[no. RR171). These guidelines were prepared in response to nosocomial outbreaks of multidrug-resistant pulmonary tuberculosis among human immunodeficiency virus (HIV)infected patients in New York city and Florida hospitals. There also appear to have been nosocomial transmissions to healthcare workers.

If you found the comprehensive supplement overwhelming, the August 30, 1991, issue of M M W R has a condensed, one-page summary of the recommendations, which accompanies a report on the tuberculosis outbreaks in four hospitals. These outbreaks appear to have resulted in part from late diagnosis of tuberculosis, late recognition of drug resistance, and delayed and/or inadequately maintained respiratory isolation procedures.

In at least one of the outbreak hospitals, implementation of CDC recommendations was followed by a decrease in cases of drug-resistant tuberculosis. It is unclear, however, whether prompt recognition, isolation, and treatment of cases alone would have prevented nosocomial transmission, or whether improved environmental controls (negative pressure, air filtration, and/or ultraviolet light treatment of air) are critical for preventing spread of tuberculosis among hospitalized acquired immunodeficiency syndrome (AIDS) patients.

By the way, if you had images of Darth Vader-like masks when you read the recommendations for "particulate respirators" in the CDC's guidelines supplement, take heart. These "respirators" are just high-efficiency, snug-fitting, disposable surgical-style face masks designed to filter out particles $1 \mu \mathrm{g}$ to $5 \mu \mathrm{g}$ in diameter, as described in the glossary of the guidelines.
The American Society for Microbiology's (ASM) Division L, Nosocomial Infections, has 578 members as of the 1990 annual report, published in August 1991. This represents an $11 \%$ increase in membership from last year's report. The Division L Chair is Dr. Bryan P. Simmons; the Chair-Elect is Dr. Robert A. Weinstein; Councilor is Dr. Donald A. Goldmann; and Alternate Councilor is Dr. Cyrus C. Hopkins.

Brief items of interest for the SHEA News or Newsletter may be sent to Robert A. W einstein, MD, SHEA, Newsletter Editor, Division of Infectious Diseases, Michael Reese Hospital, Lake Shore Drive at 31st St., Chicago, IL 60616; FAX (312) 791-3577. Copy must be typed, doublespaced, and may not exceed five pages. 


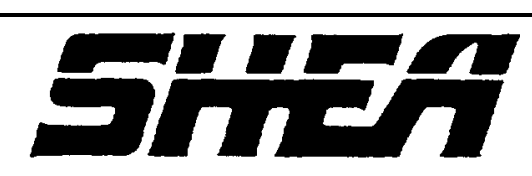

Membership Application

The Society for Hospital Epidemiology of America

Name

Degree $\quad \bullet ! \mathrm{MD} \quad \mathrm{Cl} \mathrm{PhD} \quad \square \quad$ Other

Title (in hospital epidemiology)

Institution(s) name and address

\section{City}

state

Zip code

Number of beds

Category

Cl Non-Teaching

Teaching

Business telephone

Fax

Home address

\section{City}

State

Zip code

Home telephone

Indicate preferred address for membership directory

$\square$ Home $\square$ Business

\section{Membership fees}

Non-US members please pay with draft for US dollars.

Cl Active membership-Calendar year dues: $\$ 85$

Applicants must hold a doctoral degree and should either be the head of a hospital epidemiology program or engaged on a full-time basis as a hospital epidemiologist, or employed by a federal, state, or local governmental health agency that has a direct interest in hospital epidemiology.

Cl Associate membership-Calendar year dues: $\$ 35$

Applicants must hold a doctoral degree and be participating in an appropriate training program in the field of hospital epidemiology. Proof of training must accompany this application.

Your membership fee includes a subscription to the Society's official journal, Infection Control and Hospital Epidemiology.

Please make checks payable to The Society for Hospital Epidemiology of America.

\section{Send application and remittance to: \\ SHEA Membership \\ 875 Kings Highway, Suite 200 \\ West Deptford, NJ 08096 \\ (609) 8457220 \\ (609) 853-0411 FAX}

